\title{
Reservoir sedimentation management at Gebidem Dam (Switzerland)
}

\author{
T. Meile \\ Basler \& Hofmann, Zollikofen, Switzerland \\ N.-V. Bretz \\ HYDRO Exploitation, Sion, Switzerland \\ B. Imboden \\ Electra-Massa AG, Sion, Switzerland \\ J.-L. Boillat \\ EPFL, Lausanne, Switzerland
}

\begin{abstract}
The Gebidem Dam located on the Massa River intercepts annually around $400{ }^{\prime} 000 \mathrm{~m}^{3}$ of solid material. These sediments must be evacuated by annual flushing of the reservoir over 4 to 7 days. A trend for silting in the flushing channel was observed during the last decades, leading to damageable overtopping of the lateral walls. In order to improve knowledge on input and output of sediments in the channel of Gebidem, physical and numerical modeling was performed in 1994 and in 2002 at the Laboratory of Hydraulic Constructions of the École Polytechnique Fédérale de Lausanne (EPFL). It was clearly demonstrated that the silting process is related to an anti-dunes regime progressing in the upstream direction from deposit zones which develop initially in the curves and the river confluence with Upper Rhone River. At the opposite, the clearing process starts at the upper limit of the channel and progresses by pushing the sediments downstream. The proposed solution requires an additional water supply to be introduced from the entrance of the channel. In order to optimize the clearing efficiency, the dilution supply can be progressively reduced as soon as the sediment concentration diminishes. Being aware of the importance of the annual flushing, which is the only measure to guarantee sustainable operation of the hydropower scheme, Electra-Massa continuously undertakes efforts to ensure and further improve flushing operations.
\end{abstract}

\section{INTRODUCTION}

\subsection{General remarks}

Dams significantly influence the sediment balance on watersheds. A specific management is therefore necessary to preserve normal operating conditions of the stored water as well as to keep the usable volume of the reservoir. Most of Swiss dams were built in the middle of last century and the dead zone assigned to sediment storage is generally full, leading to operation difficulties at intakes and bottom outlets (Boillat et al., 2000 and 2003). Considering that main part of the Swiss electrical production issues from hydropower schemes, it becomes obvious why reservoir sedimentation management is a major challenge.

Different solutions exist to intervene in sediment transport and deposition processes, generally related to operational and flood safety as well as to sustain environment. Complementary actions can be carried out upstream in the watershed, in the reservoir itself, at particular locations near the dam and downstream as well (Fig. 1). Among them, sediment flushing reveals an efficient solution to evacuate sediments from a reservoir, generally by opening the 


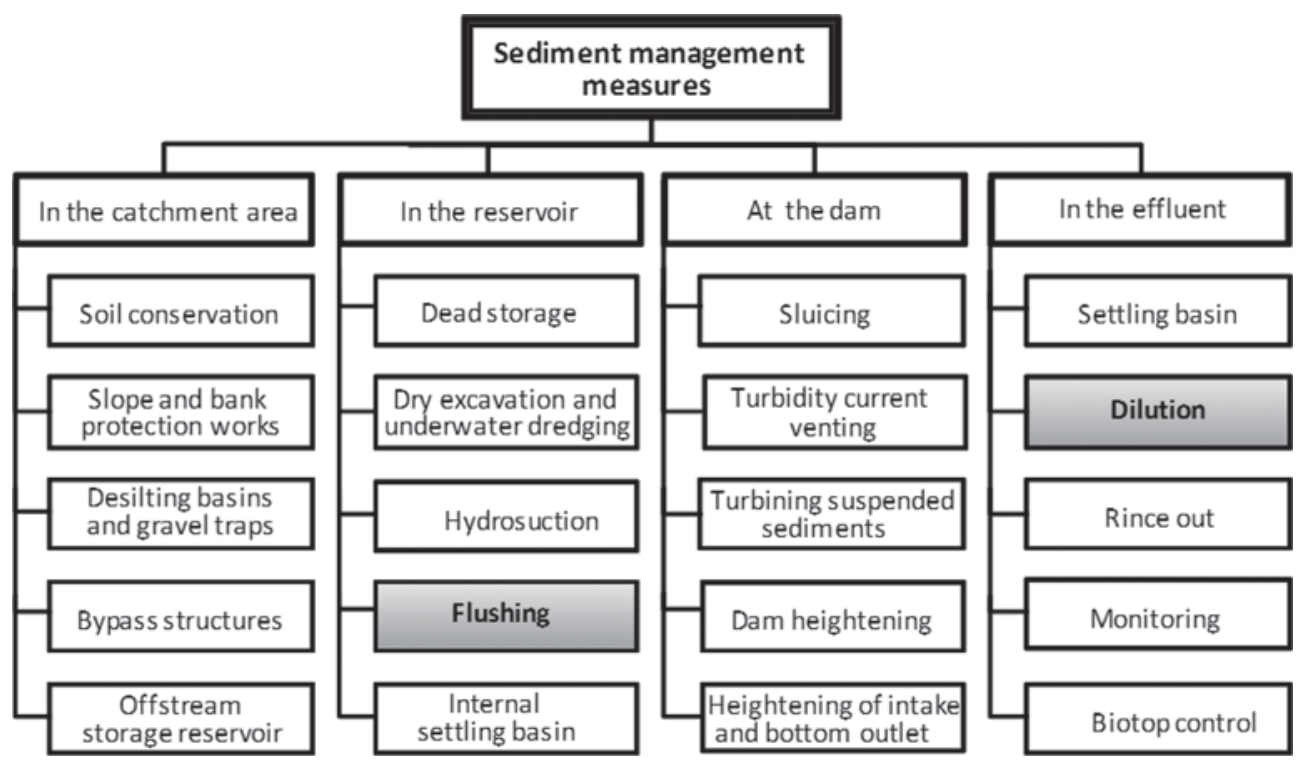

Figure 1. Inventory of measures for sediment management with focus on flushing and dilution (Boillat et al., 2003).

bottom outlet. This procedure, which is yearly applied to the reservoir sediment management at Gebidem Dam, requires a careful planning in order to avoid material and ecological damage to the downstream river reach.

Swiss legislation about reservoir management concerns two objectives, the safety of dams on the one hand and the water and fish protection on the other hand (Boillat and Pougatsch, 2000, Pougatsch et al., 2002). The safety issue is governed by the Federal Law regarding Supervision of Hydraulic Structures. Besides, the general aims of the Swiss water protection law are to avoid consequences on human health, animals and vegetation. As a consequence, the owner of a dam shall ensure as far as possible that flushing or emptying of a storage basin does not adversely affect the fauna and flora in the river downstream. Furthermore, periodical flushing requires a cantonal authorization fixing the time and duration, the maximum suspended load concentration and the conditions of post-flushing operations to clear out the riverbed.

\subsection{Massa-River catchment}

The Massa-River catchment area is $198 \mathrm{~km}^{2}$ at Gebidem Dam (1436 m a.s.1.) and culminates at $4191 \mathrm{~m}$ a.s.1. The watershed counts several glaciers (Fig. 2) with a total cover of $63.9 \%$ leading to a glacier and snowmelt dominated flow regime with $83 \%$ of the yearly runoff during only 4 months, from June to September. The mean annual runoff was estimated at about 429 Mio $\mathrm{m}^{3}$ over the period 1981 to 2000 , with a mean discharge of $13.62 \mathrm{~m}^{3} / \mathrm{s}$.

Considering the usable storage volume of $5.8 \mathrm{Mio}^{3}$ at Gebidem Dam, 74 filling and emptying cycles are theoretically possible annually. However, due to very high flow rates during summer months, Gebidem Dam is operating as a runoff river hydroelectric scheme during long periods and is acting as a huge sand and silt trap.

Due to strong glacier melting, an increase of the mean annual runoff up to $470 \mathrm{Mio}^{3}$ was observed during the last 10 years and will probably culminate at 550 to $560 \mathrm{Mio} \mathrm{m}^{3}$ in 2050 (SGHL and CHy, 2011). After this peak, a rapid decrease to about $450 \mathrm{Mio} \mathrm{m}^{3}$ in 2070 is forecasted, based on Swiss Climate Change Scenarios CH2011 of C2SM, ETHZ (Bosshard et al., 2011).

The runoff carries an important volume of sediments which amounts to about $0.1 \%$ or some 430 '000 to $4700^{\prime} 000 \mathrm{~m}^{3}$ per year since 2001 . Around $10 \%$ crosses the Gebidem Dam towards the 

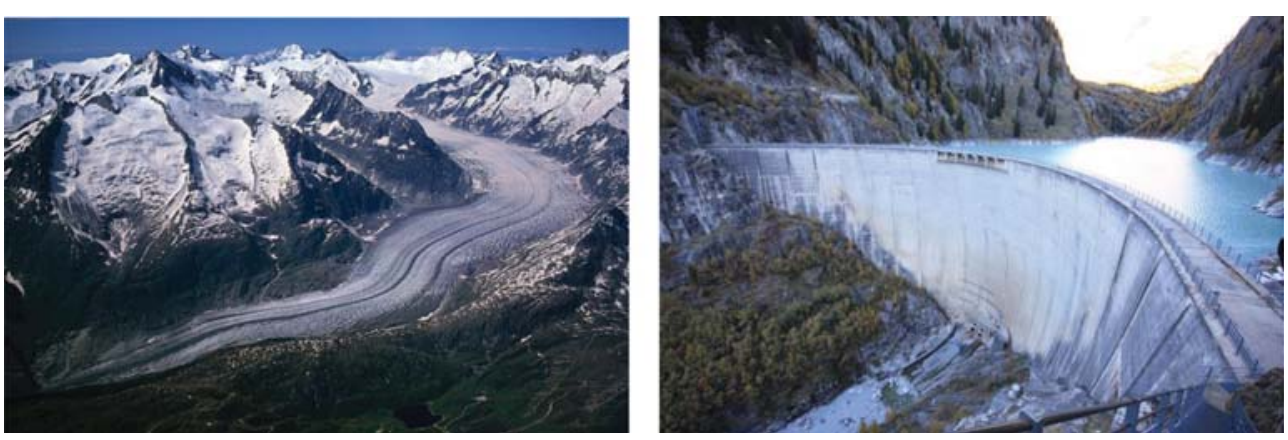

Figure 2. Left: Aletsch glacier in the Massa-River catchment (www.swisseduc.ch; 1994). Right: Gebidem Dam and lake (J. Germanier, HYDRO Exploitation SA; 2010).

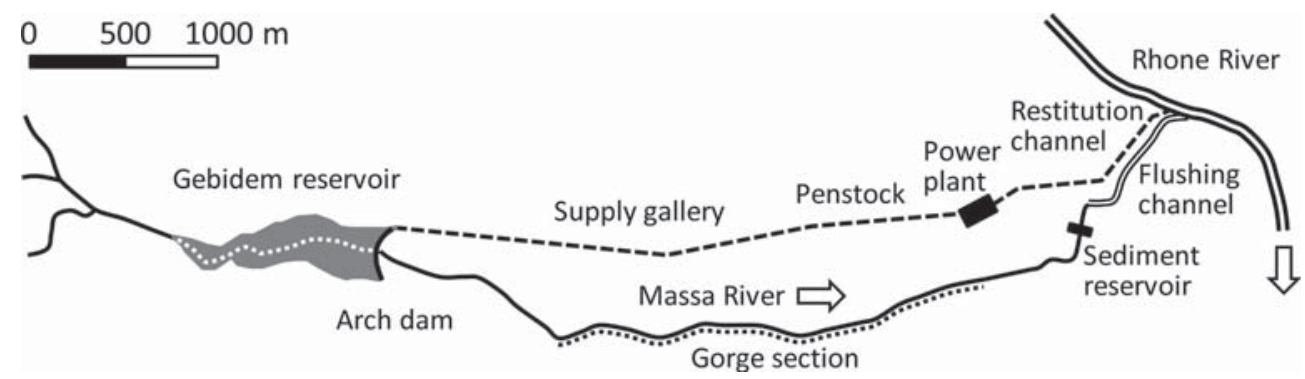

Figure 3. Elements of the hydropower scheme of Electra-Massa. Not part of scheme: sediment reservoir.

hydropower plant (Alpiq, 2010), whereas 90\% is retained and must be flushed. The sediments range from blocs/gravel to clay with a mean grain size of 1 to $3 \mathrm{~mm}$ (LCH-EPFL, 2002).

The evolution prognosis of the yearly amount of sediments due to climate change in the catchment is however not certain. Many factors such as increase of sediment availability, permafrost melting, discharge increase or floods frequency raising might be balanced by glacier lakes formation, flattened reaches with limited sediment transport or appearance of bedrock.

\subsection{Hydropower scheme of Electra-Massa SA}

The Gebidem Dam was built between 1964 and 1967 across the Massa River with the purpose of hydro-electricity production. The main elements of the hydropower scheme and the intermediate sediment reservoir (not part of the hydropower scheme) are schematized on Figure 3:

- Catchment area $198 \mathrm{~km}^{2}$

- Reservoir at $1436 \mathrm{~m}$ a.s.l. with a total volume of 9.2 $\mathrm{Mio} \mathrm{m}^{3}$ (usable volume $5.8 \mathrm{Mio} \mathrm{m}^{3}$ ).

- Arch dam $122 \mathrm{~m}$ high, with a crest spillway of $350 \mathrm{~m}^{3} / \mathrm{s}$ capacity.

- Supply gallery over 2'685 m length, with a 3.40 m diameter.

- Penstock with $2.50 \mathrm{~m}$ diameter and $1100 \mathrm{~m}$ length, under $743 \mathrm{~m}$ head.

- Power plant with a total installed power of $340 \mathrm{MW}$, shared in 3 units equipped with $55 \mathrm{~m}^{3} / \mathrm{s}$ Pelton turbines.

- Flushing channel with $1.5 \%$ longitudinal slope and $700 \mathrm{~m}$ length, 8 to $10 \mathrm{~m}$ width and 5 to $8 \mathrm{~m}$ depth.

- Intermediate sediment reservoir upstream of the flushing channel, with a maximal retention volume of about $30^{\prime} 000 \mathrm{~m}^{3}$, behind a concrete wall of about $30 \mathrm{~m}$ height. 


\subsection{Goals and importance of secure and sustainable flushing}

Without flushing operations, the total storage volume of Gebidem Dam (9.2 Mio $\left.\mathrm{m}^{3}\right)$ would be completely filled in 20 to 25 years. After 6 to 7 years without flushing, the level of the intake to the headrace tunnel would be attended by the alluvium level, leading to unacceptable high sediment load in the power plant. Already sooner, safe use of the bottom outlet could be uncertain, with some structural concerns appearing as the dam was not designed for sediment pressure. Thus, a yearly flushing must be carried out for sustainable use of the hydropower scheme.

The flushing operation is particularly demanding for the following reasons: 1. Very high amount of sediments. 2. Only few days or weeks exist during May and June with acceptable discharge conditions in the Massa and the Upper Rhone rivers. 3. Challenging general setup of the longitudinal profile with a slope reduction between the Massa River (4-5\% in sediment transport limiting reaches) and the flushing channel (1.5\%). 4. Ecological, economic and industrial constraints related to legally authorized suspended load, limited loss of water for energy production and use of the Upper Rhone River for cooling processes in the industry.

The goal of the yearly flushing can thus be summarized as: "Sustainable and secure for men, environment and infrastructures". Where sustainable in the flushing context means: "All sediments are yearly removed from the Gebidem Dam, the Massa River and Gorge as well as the flushing channel."

\section{THE ANNUAL FLUSHING}

\subsection{Processes in reservoir, Massa River and Gorge, flushing channel and Upper Rhone River}

Many different processes related with river hydraulics and sediment transport are observed during the annual flushing (Fig. 4).

Since the reservoir acts as huge sand and silt trap, finer sediments are settled down next to the dam while coarse material is accumulated in the delta which develops during summer. When opening the bottom outlet for flushing, fine sediments are first discharged leading to an abrupt increase in sediment concentration. The reservoir is then totally emptied, leading to incision of the channel bed with lateral erosion and sliding of hillside deposited material, which temporarily increase the sediment concentration. Coarser material, transported as bed load, and finer sediments in suspension pass the Gebidem Dam simultaneously.

In the Massa-River between the bottom outlet (ca. 1'328 m a.s.1.) and the entrance of the flushing channel ( $692.55 \mathrm{~m}$ a.s.1.), the bed load transport takes around 60 to 72 hours to cover the Gorge while suspended load runs near as fast as water.
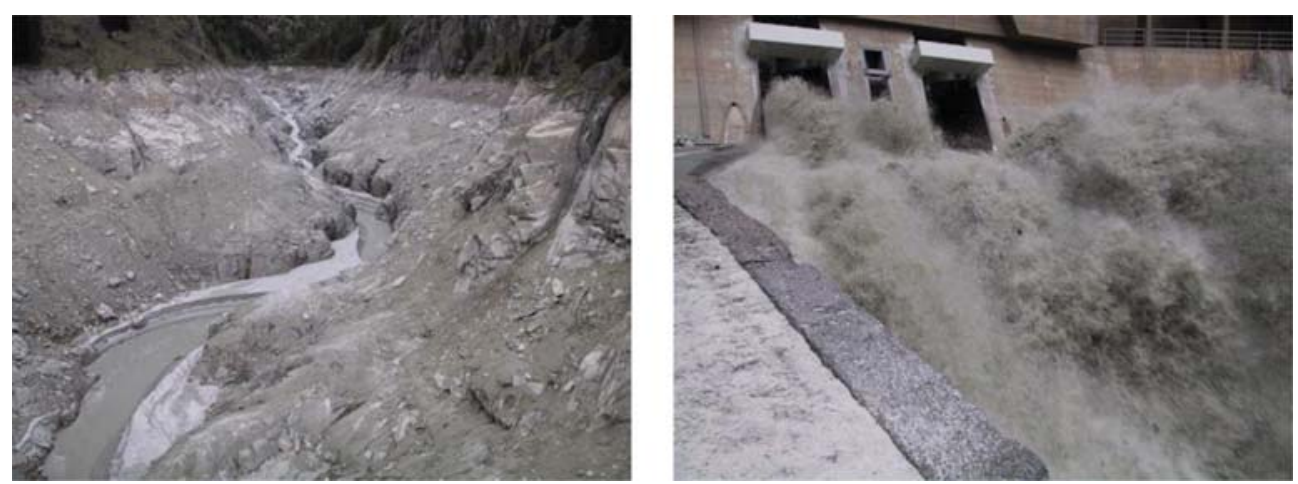

Figure 4. Flushing operation 2003. Left: Erosion and transport process in the reservoir after complete drawdown. Right: Fluid-solid mixture downstream from the bottom outlet during a flushing operation. 
Thus, transport processes in the $700 \mathrm{~m}$ long flushing channel linking the Massa-Gorge with the Rhone River are dominated during two to three days by a highly saturated flow, poor in bedload. After two or three days, a trend of deposition is observed in the channel due to a lack of sediment transport capacity. The silting process progresses from downstream to upstream, first initiated at channel bends as well as at a channel contraction and at the Rhone River confluence.

At the rivers junction, the highly concentrated Massa flow is mixed to the Rhône water over several hundred meters leading progressively to a reduction of the suspended load concentration. Bed load sediment transport at the junction depends on the total flow of both rivers. Nevertheless, an increase of the bed level is commonly observed on the right half of the Rhone River downstream from the confluence.

During emptying and clearing operations of reservoirs, according to the cantonal guidelines, a maximum sediment concentration of $10 \mathrm{ml} / 1$ has to be respected. When applying this rule, 40 mio. $\mathrm{m}^{3}$ water would be necessary to evacuate $400,000 \mathrm{~m}^{3}$ of sediments. This water volume represents $10-16 \%$ of the annual contribution. The actual flushing operations at Gebidem present sediment concentrations 4 to 6 time higher than the required value. Such a condition is admitted in this particular case, because the rocky canyon and the concrete channel downstream of the dam do not accommodate any particular natural life.

\subsection{Yearly flushing operation}

The sediment amounts which have been removed from the reservoir during the yearly flushing have been systematically evaluated since 1969 (Fig. 5). Datasets before 1991 must be considered with care as the sediment amount was directly deduced from the volume of used water and not from photogrammetric or bathymetric measurements. Furthermore, some data $(1979,1980,2008,2009,2013)$ are missing.

Considering the last twenty years, an amount of $300^{\prime} 000$ to $400^{\prime} 000 \mathrm{~m}^{3}$ needed to be flushed yearly during the appropriate period, normally from May to June. Flushing in this season is appropriate regarding the respective discharges of the Massa and Rhone rivers, and also environmental reasons. In fact, the flow increases at the end of the winter period in both rivers and succeeding floods due to strong snow and glacier melt occur at the second half of June. These floods help to restore the river bed and to evacuate the remaining fine sediment deposits.

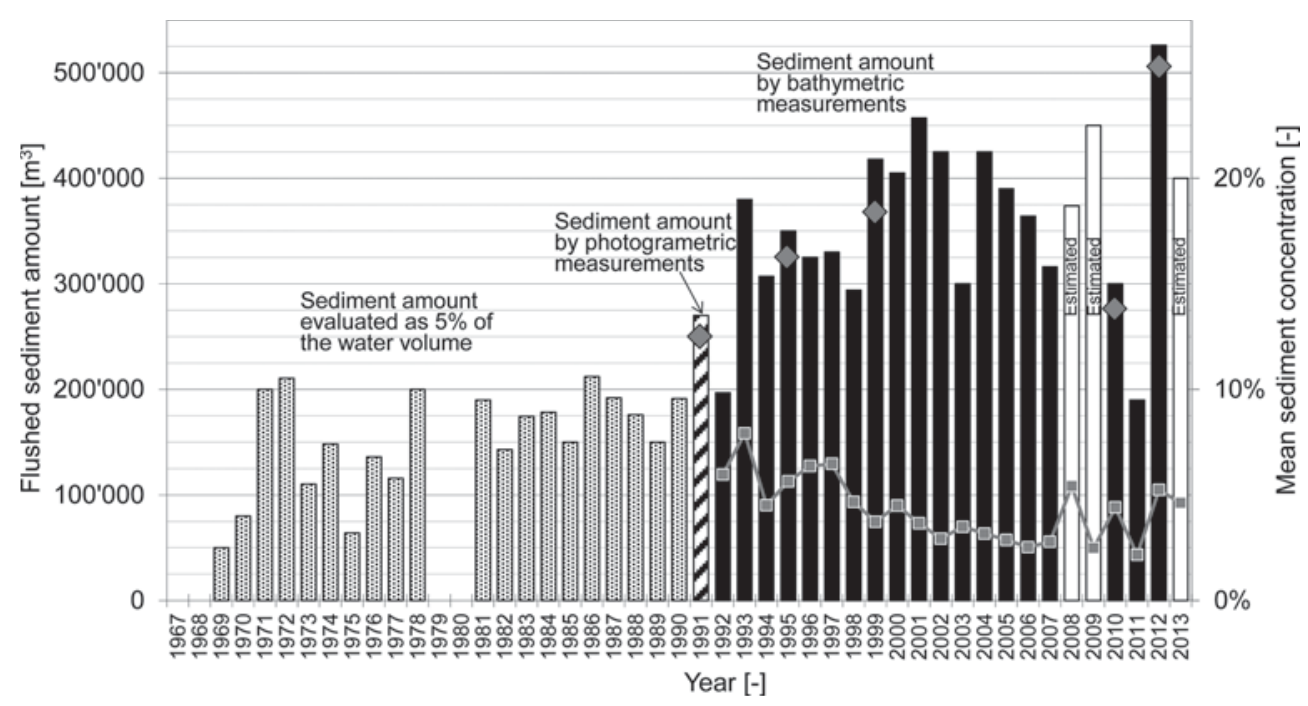

Figure 5. Yearly amount of flushed sediments and mean sediment concentration (since 1992) at Gebidem Dam (-m-). Critical flushing operations: $\diamond$. 

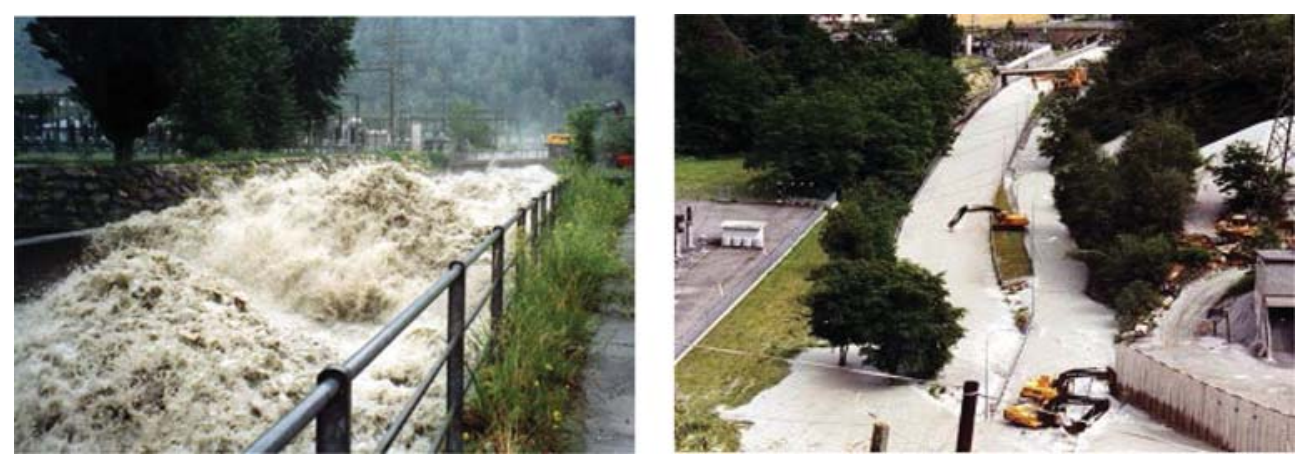

Figure 6. Left: Surface waves due to anti-dunes regime during sedimentation in the flushing channel. Right: High sediment load leading to channel overtopping in 1999.

As mentioned, the yearly flushing is a challenging operation. Several times, difficult situations appeared as documented for years 1991 and 1993, with external costs of more than 400'000.- Swiss francs (EOS, 1999). The most critical flushing operation occurred in 1999 (EOS, 2002), when permanent and competent monitoring and field operations were required to limit damages as far as possible (Fig. 6). Similar problems also occurred in 2010, for reasons still under clarification, and in 2012 with very high sediment amount and inopportune failure of a sluice gate in the intermediate sediment reservoir.

\section{CONTINUOUS EFFORTS SINCE THE ORIGIN OF THE HYDROPOWER SCHEME}

\subsection{Physical modelling in 1964}

Four physical models were operated at the Istituto di Idraulica dell'Università di Padova (Italy), two for the turbine pits, one for the restitution channel and one for the flushing channel. The tests conducted on the last model led to the actual shape of the channel and its $1.5 \%$ longitudinal slope. Lower slopes of $0.8 \%$ and $1.2 \%$ were also investigated, but they revealed insufficient to adequately manage the sediment transport. The study recommended proceeding to an annual flushing operation during 4-5 days with a discharge of $20 \mathrm{~m}^{3} / \mathrm{s}$ assuming to evacuate about $100^{\prime} 000 \mathrm{~m}^{3}$ of sediments by bedload transport and an additional amount of $400{ }^{\prime} 000 \mathrm{~m}^{3}$ being supposed transported in suspension.

From today's point of view, the study of 1964 identified the main difficulties namely the obligation to build a flushing channel. It also led to an optimization of transport capacity in the section but underestimated the part of sediments transported as bed load.

\subsection{Further tests in 1994 and 2002}

After the difficulties encountered during flushing in 1991 and 1993 and later in 1999, physical and numerical modeling were performed in 1994 (Boillat et al., 1996) and in 2002 (LCH-EPFL 2002) at the Laboratory of Hydraulic Constructions of the École Polytechnique Fédérale de Lausanne. The main purpose was to improve knowledge on relevant sediment silting and transport processes. The first study focused on the upper part of the channel, over a distance of about $400 \mathrm{~m}$. The idea was to produce an initial acceleration of the flow by insertion of a sill at the upstream end of the channel. Different alternatives with bottom deflectors and channel width reduction were simulated in search of an optimal solution. Despite some differences between the tested variants, no efficient design could be obtained (Boillat et al., 1996).

For the last study in 2002, a 1:18 down scaled physical model was built, reproducing part of the Massa gorge and the full reach of the flushing channel over a distance of about $700 \mathrm{~m}$, 

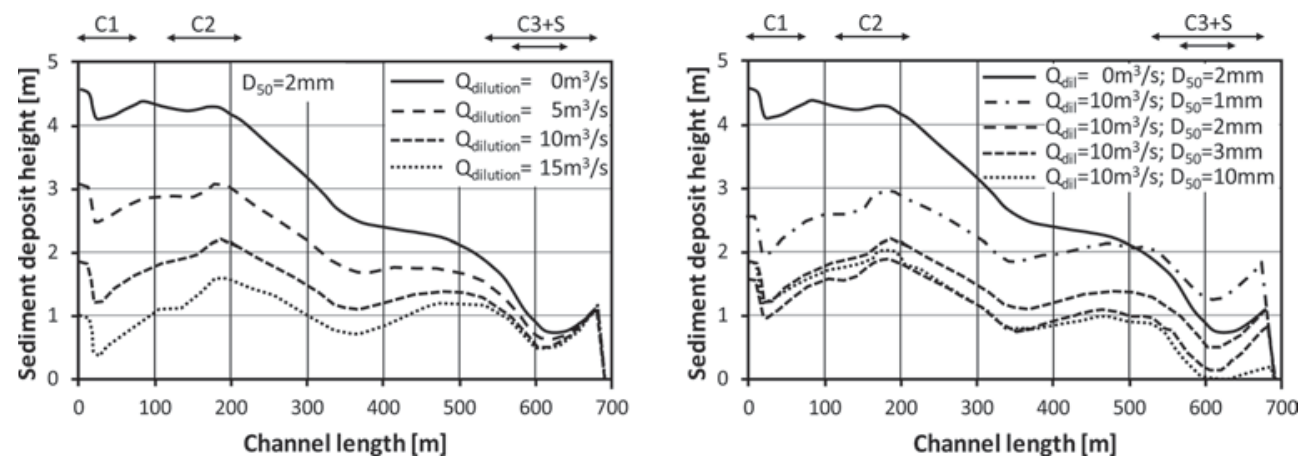

Figure 7. Maximum deposit profile in the channel related to the flushing operation of 1999. Left: Sensitivity analysis of additional clear water supply from 5 to $15 \mathrm{~m}^{3} / \mathrm{s}$, for a characteristic grain size $d_{50}=2 \mathrm{~mm}$. Right: Sensitivity analysis of the characteristic grain size $d_{50}$ from 1 to $10 \mathrm{~mm}$, for an 1 clear water supply of $10 \mathrm{~m}^{3} / \mathrm{s}$. C1, C2, C3 refer to the 3 curves where sediment deposit is initiated. S indicates the location of a shrinkage section in the channel.

up to the Rhone River (Boillat et al., 2003). Two series of tests were conducted, orientated successively towards sedimentation and erosion phases, with the aim to describe and to quantify the respective processes during flushing operations.

It could be put in evidence that silting results from an anti-dunes regime progressing towards upstream. This process is initiated in the existing curves of the channel, where deposit starts in the inner part before progressively covering the whole section. On the other hand, sediment clearing progress from the upper boundary of the channel, eroding and evacuating deposits under a flow stream effect (LCH-EPFL, 2002).

Based on the experimental results, it became obvious that an additional discharge of clear water was required at the upper limit of the channel to increase the sediment transport capacity. In order to evaluate the influence of this dilution flow, a non-steady numerical model was applied down to the Rhone River. After calibration with reference to experimental results as well as to the documented flushing of the year 1999, a sensitive analysis about sediment grain size distribution and additional dilution discharge (Fig. 7) was carried out.

\subsection{The proposed solution}

Physical model tests and numerical simulations opened out into recommendations for the flushing procedure. It has been suggested that an additional water supply had to be introduced at the upstream end of the channel, as soon as the sediment layer reaches $1.5 \mathrm{~m}$ depth at a control section located about $200 \mathrm{~m}$ from the entrance of the channel. This reference corresponds to the place where the sediments depth is the highest.

The dilution discharge has to be increased progressively in order to avoid a rapid accumulation of sediments at the input location, leading to a local sediment accumulation and consequently to the water surface increase. In order to optimize the clearing efficiency, the dilution supply will progressively be reduced as soon as the sediment concentration diminishes.

\section{THE DILUTION SUPPLY TUNNEL}

\subsection{The project}

According to the proposed solution, the project consisted to build a water supply tunnel, originated from the neighboring low chute Massaboden hydropower scheme (Fig. 8).

The $506 \mathrm{~m}$ long tunnel with $4.5 \%$ longitudinal slope has three types of sections adapted to geological conditions with around $2.50 \mathrm{~m}$ width and $2.50 \mathrm{~m}$ height. This device is able to provide a dilution discharge up to $15 \mathrm{~m}^{3} / \mathrm{s}$ and thus to manage the flooding risk in the flushing 


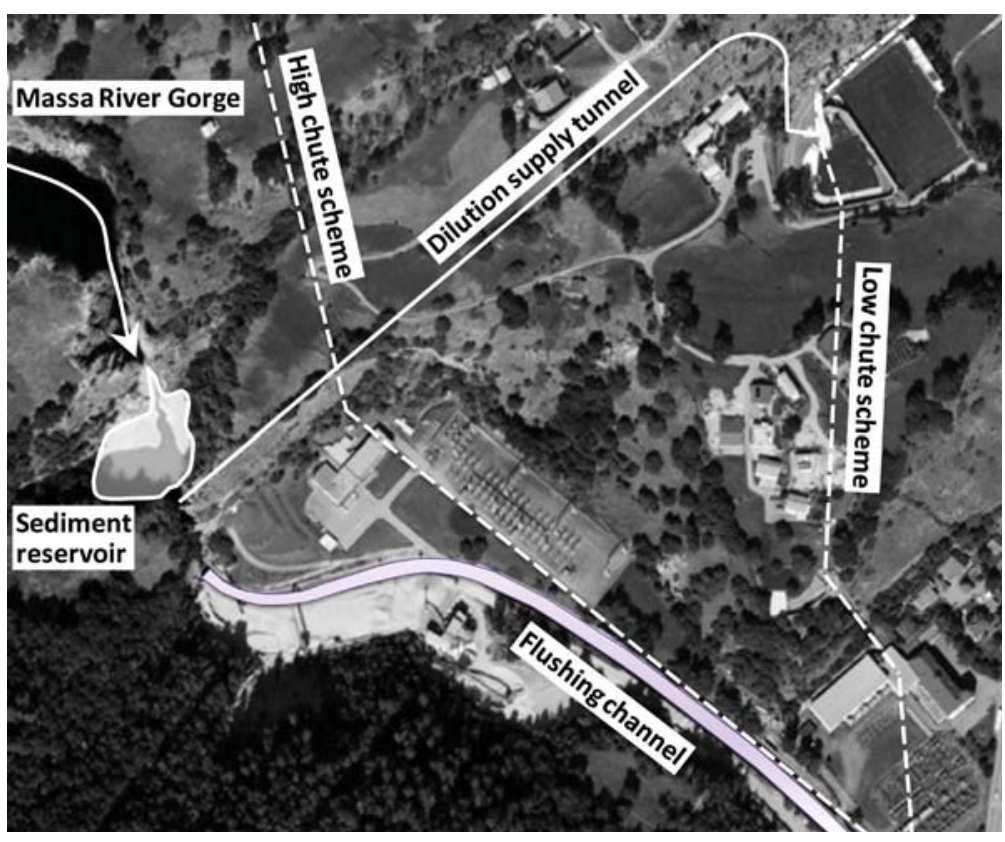

Figure 8. Schematic view of the dilution supply tunnel project.
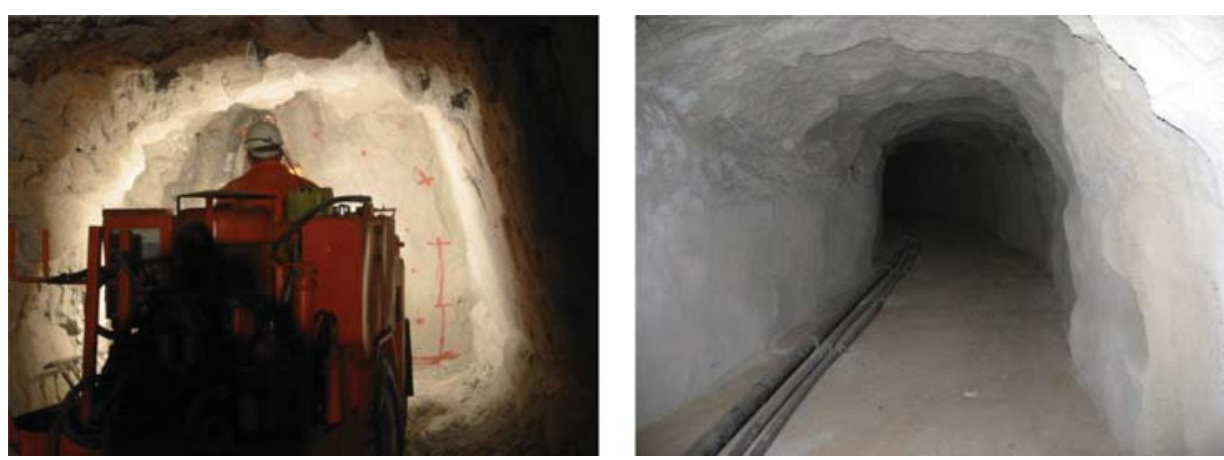

Figure 9. The dilution supply tunnel under construction (on the left) and completed (on the right).

channel. Furthermore, if considering the reduced time of the flushing operation and the head difference between the Gebidem Dam and the low chute scheme, the investment will be amortized in less than 10 years.

This example of a sediment management measure at the effluent by dilution (Fig. 1) shows the positive contribution of additional water for clearing the deposit and reducing the sediment concentration at the outflow.

\subsection{The construction}

The construction was realized between September 2005 and August 2006. The tunneling method was the traditional drill-and-blast, adequate for such a small section (Fig. 9). First blast was made on 16.11.2005 and the last one on 18.07.2006. A short access tunnel 


\begin{tabular}{|c|c|c|c|c|c|}
\hline \multirow[t]{2}{*}{ Year } & \multirow{2}{*}{$\begin{array}{c}\text { Water volume } \\
\text { Massa River } \\
\mathrm{m}^{3}\end{array}$} & \multirow{2}{*}{$\begin{array}{c}\text { Water volume } \\
\text { Supply shaft } \\
\mathrm{m}^{3}\end{array}$} & \multirow{2}{*}{$\begin{array}{c}\text { Sediment } \\
\text { Volume } \\
\mathrm{m}^{3}\end{array}$} & \multirow{2}{*}{$\begin{array}{c}\text { Energy } \\
\text { Consumption } \\
\text { MWh }\end{array}$} & $\begin{array}{l}\text { Energy per } \\
\text { Sed. volume }\end{array}$ \\
\hline & & & & & \\
\hline 2004 & $13^{\prime} 400^{\circ} 000$ & 0 & $425^{\prime} 000$ & $22^{\prime} 110$ & 0.0520 \\
\hline 2005 & $13^{\prime} 6000000$ & 0 & $390^{\prime} 000$ & $22^{\prime} 440$ & 0.0575 \\
\hline 2006 & $14^{\prime} 4000000$ & 0 & $364^{\prime} 000$ & 23760 & 0.0653 \\
\hline 2007 & $11^{\prime} 3700000$ & $1^{\prime} 860^{\prime} 000$ & $316^{\prime} 000$ & $18^{\prime} 928$ & 0.0599 \\
\hline 2008 & 6.250000 & $3^{\prime} 230^{\prime} 000$ & $373^{\prime} 750$ & $10^{\prime} 603$ & 0.0284 \\
\hline 2009 & 128700000 & $5^{\prime} 200^{\prime} 000$ & $450^{\prime} 000$ & 21704 & 0.0482 \\
\hline 2010 & 5040000 & $1^{\prime} 800^{\prime} 000$ & $300^{\prime}, 000$ & 8478 & 0.0283 \\
\hline 2011 & 7440000 & $1^{\prime} 320^{\prime} 000$ & $190^{\prime} 000$ & 12'395 & 0.0652 \\
\hline 2012 & 62200000 & $31^{\prime} 816^{\prime} 000$ & 526000 & $13^{\prime} 126$ & 0.0250 \\
\hline 2013 & $5^{5} 563^{3} 0000$ & $3^{\prime} 086^{\prime} 000$ & $400^{\prime} 000$ & 9457 & 0.0236 \\
\hline
\end{tabular}

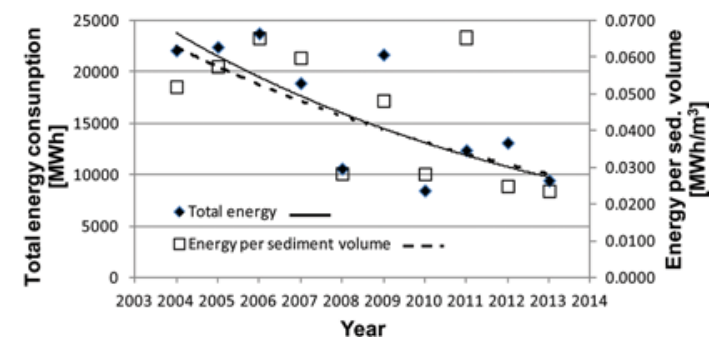

Figure 10. Water supply and evacuated sediment volume during flushing operations, before and after set up of the dilution system in 2007 , as well as related energy consumption.

was first excavated, about $20 \mathrm{~m}$ near the lower end of the dilution tunnel in the Massa gorge.

The connection of the dilution supply tunnel to the neighboring scheme was achieved only one year later, due to the delayed completion of the transformation works on this scheme.

\subsection{New flushing concept and first experiences}

The new flushing concept consists to evacuate the sediments from the Gebidem reservoir rapidly with a large discharge, to create an intermediate stock of sediments in the Massa River between the dam and the Rhone River and to wash the Gorge with a reduced discharge, allowing the filling up of the reservoir for the reactivation of energy production. When the sediments layer reaches a certain depth in the flushing channel, the gate of the dilution supply tunnel is opened and its discharge is controlled in function of the evolution of the sediment level.

The first experience of the new flushing concept was successfully made in 2007. With $11^{\prime} 370^{\prime} 000 \mathrm{~m}^{3}$ of water from the Massa River and 1'860'000 $\mathrm{m}^{3}$ from the neighboring scheme, the dilution supply proved its efficiency. Considering differentiated energy coefficients for Gebidem high head and Massaboden low chute schemes, the total energy consumption as well as the energy per sediment volume unit used for the flushing operation could be estimated. The values obtained before and after introduction of the dilution supply in 2007 show a significant trend towards energy efficiency (Fig. 10).

\section{FURTHER EFFORTS AND FUTURE CHALLENGES}

Despite the long experience of operating Gebidem draw-down for flushing and additional flexibility offered by the dilution supply tunnel, some residual risk remains due to uncertainties in meteorological forecast, sudden weather changes (temperature, clouds, precipitations) in the high mountain catchment, risk associated to handling and state of the infrastructure of the intermediate sediment reservoir as well as sliding, erosion and transport processes of sediments in the reservoir or other unexpected difficulties.

The owner of the Gebidem Dam, Electra-Massa, pursues thus systematic and continuous efforts to ensure further improvement of flushing operations according to the field of actions summarized in Table 1.

The major challenge in the following decades will be to catch the period for secure and sustainable flushing under tendency of decreasing Upper Rhone discharge (lower glacier cover with sooner snowmelt) and increasing Massa discharge up to the year 2050 (high glacier cover). 
Table 1. Systematic pursued efforts to ensure further improvement of flushing.

\begin{tabular}{|c|c|c|}
\hline Field of actions & Action & Goal \\
\hline $\begin{array}{l}\text { Optimization of } \\
\text { discharge } \\
\text { distribution } \\
\text { between Massa } \\
\text { and Upper-Rhone } \\
\text { rivers }\end{array}$ & $\begin{array}{l}\text { - Precise discharge and weather predictions } \\
\text { - Ensure use of neighboring power plant } \\
\text { with transfer of } 7 \mathrm{~m}^{3} / \mathrm{s} \text { from Massa } \\
\text { to Rhone } \\
\text { - Best use of bottom outlet at Gebidem Dam } \\
\text { - Integration of neighboring storage plants } \\
\text { to increase Upper-Rhone discharge }\end{array}$ & $\begin{array}{l}\text { - Best moment for flushing } \\
\text { - Dilution of sediment } \\
\text { concentration in } \\
\text { Upper-Rhone } \\
\text { - Avoid system overload } \\
\text { - Dilution of sediment } \\
\text { concentration in } \\
\text { Upper-Rhone }\end{array}$ \\
\hline $\begin{array}{l}\text { Competent and } \\
\text { focused use of } \\
\text { flushing } \\
\text { infrastructure }\end{array}$ & $\begin{array}{l}\text { - Extensive documentation of yearly flushing } \\
\text { - Ensure competences of key persons } \\
\text { - Punctual upgrading measurement system }\end{array}$ & $\begin{array}{l}\text { Best practice, continuous } \\
\text { learning, sharing and } \\
\text { transmission of knowledge }\end{array}$ \\
\hline $\begin{array}{l}\text { Continuous } \\
\text { maintenance } \\
\text { of infrastructure }\end{array}$ & $\begin{array}{l}\text { - Renovation flushing channel (2015-2017) } \\
\text { - Regular use and maintenance of movable } \\
\text { component parts }\end{array}$ & $\begin{array}{l}\text { - Certain use of } \\
\text { infrastructure } \\
\text { - In time perception of } \\
\text { necessity for maintenance }\end{array}$ \\
\hline $\begin{array}{l}\text { Controlling the } \\
\text { residual risk }\end{array}$ & $\begin{array}{l}\text { - Precisely defined locations for intervention } \\
\text { - Knowing flow paths of water overtopping } \\
\text { - Mobile equipment for goods protection }\end{array}$ & $\begin{array}{l}\text { - Enhance security for men } \\
\text { - Reduce damage } \\
\text { - Reduce loss of income }\end{array}$ \\
\hline
\end{tabular}

\section{CONCLUSIONS}

Reservoir sedimentation management is an essential task worldwide. In Switzerland, where most dams are dedicated to electricity production, mainly by storage plants, the dead storage, designed to accumulate the sediment deposit is generally completely filled. This is a source of problems regarding the safe operation of turbines and bottom outlet devices.

In the particular case of Gebidem Dam, the power scheme functioning is maintained safe thanks to annual flushing operations. However, considering the high amount on sediments to evacuate, the flushing channel suffers a silting process, leading to unacceptable overtopping of the lateral walls. The introduction of an additional clear water supply at the upper limit of the channel was proposed with the aim to reduce the sediment concentration and to control the settling process in the channel.

This solution was first tested on physical model, providing reference data for the calibration of a numerical model. A sensitivity analysis on the dilution discharge and the characteristic grain size allowed then to define operation rules for flushing.

The conceptual idea could be achieved by water diversion from a neighboring low chute hydropower scheme in 2006. Recent experiences with a dilution water supply confirm the efficiency of this solution. However, residual risk cannot be totally excluded and continuous and systematic efforts need to be undertaken for safe and sustainable flushing in the future. These concern namely the field of actions "optimization of discharge distribution between Massa and Upper-Rhone".

The acquired experience about the Gebidem reservoir sediment management allows tending towards optimal flushing operations. This issue could only be attained thanks to a great perseverance, confirming the absolute necessity to consider the problem of reservoir sedimentation already in the early stage of the design for new projects.

\section{REFERENCES}

Alpiq. 2010. Electra-Massa, Gebidem, Balades hydroélectriques.

Boillat, J.-L., Dubois, J., De Cesare, G., Bollaert, E. 2000. Sediment management examples in Swiss Alpine reservoirs. Proceedings International Workshop and Symposium on Reservoir Sedimentation Management, Tokyo, Japan. 
Boillat, J.-L., Dubois, J., Lazaro, P. 1996. Eintrag und Austrag von Feststoffen im Spülkanal von Gebidem. Modellversuche und numerische Simulation. Symposium an Verlandung von Stauseen und Stauhaltungen, Sedimentprobleme in Leitungen und Kanälen, 28./29. März 1996, ETH Zürich, Mitteilung Nr. 142 der Versuchsanstalt für Wasserbau, Hydrologie und Glaziologie (VAW), pp. 151-170.

Boillat, J.-L., Oehy, Ch., Schleiss, A. 2003. Reservoir Sedimentation Management in Switzerland. The 3rd World Water Forum, Challenges to the Sedimentation Management for Reservoir Sustainability, pp. 143-158.

Boillat, J.-L., Pougatsch, H. 2000. State of the art of sediment management in Switzerland. Proceedings International Workshop and Symposium on Reservoir Sedimentation Management, Tokyo, Japan, pp. 143-153.

Bosshard, T., Fischer, A., Kress, A., Kull, C., Liniger, M.A., Lustenberger, A. und Scherrer, S. 2001. Swiss Climate Change Scenarios CH2011.

EOS. 1999. Chenal de la Massa à Bitsch, Remarques et réflexions. From Bretz, N.-V. for Electra-Massa (unpublished).

EOS. 2002. Note interne no 2002/293, Chenal de la Massa à Bitsch, Conduite enterrée pour la dilution. (unpublished).

Istituto di Idraulica dell'Università di Padova. 1964. Essais sur modèles réduits des ouvrages de restitution de la centrale de Bitsch.

LCH-EPFL. 1994. Etude expérimentale sur modèle hydraulique du chenal de chasse de la Massa à Bitsch. Internal Report, Laboratory of Hydraulic Constructions, EPF-Lausanne, Switzerland.

LCH-EPFL. 2002. Gestion du transport solide lors de la purge annuelle du barrage de Gebidem. Modélisations physique et numérique des écoulements et du transport solide dans le chenal de chasse de la Massa à Bitsch. Internal Report n ${ }^{\circ} 8$, Laboratory of Hydraulic Constructions, EPF-Lausanne, Switzerland.

Pougatsch et al. 2002. Sécurité des ouvrages d'accumulation. Dam safety guidelines. Swiss Federal Office for Water and Geology, Bern, Switzerland.

Schweizerische Gesellschaft für Hydrologie und Limnologie (SGHL), Hydrologische Kommission (CHy). 2011. Auswirkungen der Klimaänderung auf die Wasserkraftnutzung-Synthesebericht. Beiträge zur Hydrologie der Schweiz, Nr. 38, 28 S., Bern. 